\title{
FARMERS' HOUSEHOLD WASTE DISPOSAL BEHAVIOR AND ITS INFLUENCING FACTORS IN DEVELOPING COUNTRIES: EVIDENCE FROM JIANGSU, CHINA
}

\author{
LIU, R. ${ }^{1}-$ WANG, Y.$^{2 *}$ \\ ${ }^{I}$ School of Economics and Management, Beijing University of Chemical Technology \\ Beijing 100029, China \\ (phone: +86-010-6444-8681; fax: +86-010-6444-8681) \\ ${ }^{2}$ Department of Aviation Safety Management, Civil Aviation Management Institute of China \\ Beijing 100102, China \\ (phone: +86-010-5622-5603; fax: +86-010-5622-5603) \\ ${ }^{*}$ Corresponding author \\ e-mail:405279930@qq.com
}

(Received $8^{\text {th }}$ Mar 2019; accepted $1^{\text {st }}$ May 2019)

\begin{abstract}
The improper disposal of household waste is a major reason for the deterioration of rural ecological environment in developing countries. As the main producer of rural household waste, farmers' behavior is very important to solve the problem. Based on the data of 671 surveys in Jiangsu, China, the influencing factors of farmers' household waste disposal behavior and their hierarchical relationships were determined by Logit-ISM model. The study finds that there are 7 factors that significantly affect household waste disposal behavior of farmers, among which Major domestic fuel, Clearance of centralized waste dump site and Neighbor's way of disposing household waste are the surface factors; Identifying capacity for pollutants, Major economic source and Availability of centralized waste disposal facility are the intermediate factors; Fixed-point waste disposal policy and its implementation effect is the deep- rooted factor.
\end{abstract}

Keywords: farmer household behavior, Lewin's behavior model, Logit model, ISM method, sorted reachability matrix, interpretative structure model

\section{Introduction}

The construction of ecological civilization has increasingly become a hot topic of common concern to mankind. All countries in the world are committed to exploring the road of harmonious coexistence between human and nature. Due to the dominant position of developed countries, relevant organizations and associations mainly focused on the prevention and control of industrial pollution and urban pollution (Petraru and Gavrilescu, 2010; Gong et al., 2019), and less on rural environmental issues. However, for the vast majority of developing countries, rural areas are the largest hinterland of biological resources, carrying the majority of the country's population. Construction of rural ecological civilization occupies a more fundamental position. In the past, kitchen residues were the main part of rural household waste, which was recycled reasonably, resulting in little pollution to the surrounding environment. In recent years, with the rise of the economy in developing countries, the consumption structure of rural residents has changed greatly. As a result, the composition of rural household waste becomes more complex. Plastic products, electronic waste and other non-decomposable items are becoming more common (Hakami and Seif, 2015; Du et al., 2018). The original selfpurification ability of rural areas can hardly play an effective role. The impact of household waste on rural ecological environment is becoming increasingly serious. 
This phenomenon is particularly prominent in China. Due to the long-standing views of farmers, it is quite common for waste to be dumped at will, resulting in serious soil pollution (Zeng et al., 2018), water pollution (Zhang et al., 2013) and air pollution (Jin et al., 2006). Ultimately, the health of villagers has been damaged. It can be seen that the control of household waste discharge arbitrarily is a very important task. However, the current rural household waste management method is a government-dominant model, which marginalizes farmers and makes them spectators, passives and even adversaries. It needs to be deeply realized that farmers are not only the producers of household waste, but also the direct victims of the pollution. Farmer should be the core subject of the governance of rural environmental problems. However, previous studies mainly focused on the productive environmental behavior of farmers, and paid less attention to the impact of farmers' daily life behavior on the environment.

This paper analyses the impact of farmers' daily life behavior on the environment from their perspective, which is not only related to the quality of life of 900 million rural populations in China, but also directly affects the sustainable development of China's economy. Meanwhile, as a representative of developing countries, China's rural household waste disposal problem is a microcosm of the same problem in developing countries. This study can provide new ways for other developing countries to promote rural ecological environment construction.

\section{Theoretical basis and variable selection}

\section{Theoretical basis}

Since the 1960s, the process of industrialization and urbanization has been accelerating. Environmental protection has gradually become a consensus of mankind. Sociological circles have begun to pay close attention to this problem. In 1978, American sociologists Catton and Dunlap published their paper Environmental Sociology: A New Paradigm, which clearly pointed out that Environmental Sociology should focus on the interaction between environment and human society. Subsequently, the famous Japanese sociologist Torigoe Hiroyuki emphasized that the subject of environmental pollution is human itself. Meanwhile, Kurt Lewin pointed out that individual behavior is the product of the interaction between individual and environment. He put forward the famous Lewin behavior model, namely $B=F(P, E)$, in which $B$ is human behavior; $P$ is the internal condition and characteristics of an individual, $E$ refers to the external environment. Lewin's behavior model provides a solid theoretical basis for people to explore human behavior including environmental behavior.

\section{Variable selection}

With the comprehensive study of scholars, based on Lewin behavior model, this paper analyses the influencing factors of farmers' household waste disposal behavior from the perspectives of personal and environment. Personal factors can be divided into physiological characteristics and psychological characteristics. Physiological characteristics are age, gender and cadre status; psychological characteristics include recognition of fixed-point waste disposal, perception of the surrounding environment, and knowledge of environmental protection. Environmental factors can be divided into family environment, social environment and natural environment. Family environment 
includes education environment and business environment; social environment includes propaganda and education, incentive and punishment, policy system, organizational setting, infrastructure and social culture; natural environment in this paper mainly refers to geographical location. Variable selection and measurement are shown in Table 1.

Table 1. Variable selection and measurement

\begin{tabular}{|c|c|c|}
\hline \multicolumn{2}{|r|}{ Variable } & Variable measurement and assignment \\
\hline $\mathrm{X} 1$ & Sex (Schahn and Holzer, 1990) & Male $=0 ;$ Female $=1$ \\
\hline $\mathrm{X} 2$ & Age(Yang et al., 2017) & $\begin{array}{l}18-24 \text { years old }=1 ; 25-34 \text { years old }=2 ; 35-44 \text { years } \\
\text { old }=3 ; 45-54 \text { years old }=4 ; 55-64=5\end{array}$ \\
\hline $\mathrm{X} 3$ & Cadre status(Yang et al., 2017) & Yes $=0 ; \mathrm{No}=1$ \\
\hline $\mathrm{X} 4$ & $\begin{array}{l}\text { Cognition of the necessity of fixed-point disposal } \\
\text { of waste (Bamberg, 2003; Oyekale, 2018) }\end{array}$ & $\begin{array}{c}\text { Absolutely unnecessary }=0 ; \text { Unnecessary }=1 ; \\
\text { Uncertainty }=2 ; \text { Necessary; Extremely necessary }=3\end{array}$ \\
\hline $\mathrm{X} 5$ & $\begin{array}{l}\text { Cognition of the hazard of household waste } \\
\text { disposal at will (Yokoo et al., 2018) }\end{array}$ & $\begin{array}{c}\text { No influence }=0 ; \text { Less influence }=1 ; \text { Uncertainty }=2 ; \\
\text { Some influence }=3 \text {; Great influence }=4\end{array}$ \\
\hline X6 & $\begin{array}{c}\text { Satisfaction degree of the sanitary environment of } \\
\text { your villages(Wang and Kang, 2019) }\end{array}$ & $\begin{array}{c}\text { Extremely satisfactory }=0 ; \text { Basic satisfactory }=1 ; \\
\text { Uncertainty }=2 ; \text { Dissatisfaction }=3 ; \text { Extremely } \\
\text { unsatisfactory }=4\end{array}$ \\
\hline $\mathrm{X} 7$ & $\begin{array}{l}\text { Attention to environmental protection } \\
\text { information(Arcury, 1990; Estrada et al., 2017) }\end{array}$ & $\begin{array}{l}\text { Attention at all times }=0 ; \text { Constant attention }=1 ; \\
\text { Occasional attention }=2 ; \text { Little attention }=4\end{array}$ \\
\hline $\mathrm{X} 8$ & Identifying capacity for pollutants(Milfont, 2012) & $\begin{array}{c}\text { Extremely agree }=0 ; \text { Basic agree }=1 ; \text { Uuncertainty }=2 ; \\
\text { Disapproval }=3 ; \text { Extremely disapproval }=4\end{array}$ \\
\hline X9 & $\begin{array}{l}\text { Family educational level(Poortinga et al., 2003; } \\
\qquad \text { Ma et al., 2009) }\end{array}$ & $\begin{array}{c}\text { Uneducated }=1 ; \text { Primary }=2 ; \text { Junior }=3 \text {; Senior } / \\
\text { Secondary }=4 ; \text { College/Undergraduate }=5 \text {; Graduate and } \\
\text { above }=6\end{array}$ \\
\hline $\mathrm{X} 10$ & Family annual income(Dorina, 2016) & $\begin{array}{l}\text { Less than } 50 \mathrm{~K}=1 ; 50-100 \mathrm{~K}=2 ; 100-150 \mathrm{~K}=3 ; 150- \\
200 \mathrm{~K}=4 ; 200 \mathrm{~K} \text { or } \operatorname{more}=5(1 \mathrm{~K}=1000 \mathrm{CNY})\end{array}$ \\
\hline $\mathrm{X} 11$ & $\begin{array}{l}\text { Number of migrant workers(Jiang and Yuan, } \\
\text { 2013) }\end{array}$ & According to the specific data value of the survey \\
\hline $\mathrm{X} 12$ & Major domestic fuel(Han et al., 2018) & $\begin{array}{c}\text { Coal=Wood }=\text { Straw and other wilting crops }=0 ; \\
\text { Liquefied gas }=\text { Electricity }=1\end{array}$ \\
\hline $\mathrm{X} 13$ & Major economic source(Ma et al., 2009) & Farming income $=0 ;$ Wage income $=1$ \\
\hline $\mathrm{X} 14$ & $\begin{array}{l}\text { Advocacy on the benefits of designated waste } \\
\text { disposal(Steg, 2008; Hakami and Seif, 2015) }\end{array}$ & $\begin{array}{l}\text { Frequent publicity }=0 ; \text { Occasional publicity }=1 ; \\
\text { Unclear }=2 ; \text { Seemingly no }=3 \text {; Completely no }=4\end{array}$ \\
\hline $\mathrm{X} 15$ & $\begin{array}{l}\text { Call for fixed-point waste disposal(Miliute- } \\
\text { Plepiene et al.,2016; Seacat and Boileau, 2018) }\end{array}$ & $\begin{array}{l}\text { Frequent call }=0 ; \text { Occasional call }=1 ; \text { Unclear }=2 ; \\
\text { Seemingly no }=3 ; \text { No call at all }=4\end{array}$ \\
\hline $\mathrm{X} 16$ & $\begin{array}{l}\text { Management of discarding waste at will(Li et al., } \\
\text { 2016) }\end{array}$ & $\begin{array}{c}\text { Ignorance= }=; \text { Verbal warning }=1 ; \text { Notification of } \\
\text { criticism }=2 ; \text { Fine }=3\end{array}$ \\
\hline $\mathrm{X} 17$ & $\begin{array}{l}\text { Fixed-point waste disposal policy and its } \\
\text { implementation effect(Refsgaard and Magnussen, } \\
\text { 2009; D'Amato et al., 2016) }\end{array}$ & $\begin{array}{l}\text { Yes, the implementation effect is good }=0 \text {; Yes, but the } \\
\text { implementation effect is not good }=1 \text {; Yes, but no } \\
\text { specific implementation }=2 \text {; Not very clear }=3 \text {; No } \\
\text { relevant measures }=4\end{array}$ \\
\hline $\mathrm{X} 18$ & $\begin{array}{l}\text { Inspection of fixed-point waste recycling(Hage et } \\
\text { al., 2018) }\end{array}$ & $\begin{array}{l}\text { Frequent check }=0 ; \text { Occasional check }=1 ; \text { Unclear }=2 ; \text { As } \\
\text { if no check }=3 \text {; No check at all }=4\end{array}$ \\
\hline X19 & $\begin{array}{c}\text { Setting up of professional waste disposal } \\
\text { departments or full-time personnel(Guagnano et } \\
\text { al., 1995) }\end{array}$ & Never $=0$; Occasionally $=1 ;$ Always $=2$ \\
\hline $\mathrm{X} 20$ & $\begin{array}{l}\text { Availability of centralized waste disposal facility } \\
\text { (Young et al., 1990; Abbott et al., 2013) }\end{array}$ & Yes $=0 ; \mathrm{No}=1$ \\
\hline $\mathrm{X} 21$ & $\begin{array}{l}\text { Distance to centralized waste disposal } \\
\text { facilities(Jenkins et al., 2003; Struk, 2017) }\end{array}$ & Very close $=0 ;$ Slightly distant $=1 ;$ Far away $=2$ \\
\hline $\mathrm{X} 22$ & $\begin{array}{l}\text { Clearance of centralized waste dump site (Kuo } \\
\text { and Perrings, 2010; Lee et al., 2017) }\end{array}$ & $\begin{array}{l}\text { Irregular, Long intervals }=0 ; \text { Regular, low } \\
\text { frequency }=1 ; \text { Regular, high frequency }=2\end{array}$ \\
\hline $\mathrm{X} 23$ & $\begin{array}{l}\text { Neighbor's way of disposing household waste } \\
\text { (Videras et al., 2012; Czajkowski et al., 2017) }\end{array}$ & $\begin{array}{l}\text { Throw it in front of or behind the house }=\text { Pour into the } \\
\text { riverside, roadside or ditch=Open storage=Open } \\
\text { burning=Landfill nearby }=0 \text {; Use waste as fertilizer }=\text { Sell } \\
\text { off after classification }=\text { Transport to designated waste } \\
\text { pool=1 }\end{array}$ \\
\hline $\mathrm{X} 24$ & Distance to the city center(Huang et al., 2012) & Very close $=0 ;$ Slightly distant $=1 ;$ Far away $=2$ \\
\hline
\end{tabular}




\section{Sample characteristics and research method}

\section{Sample characteristics}

The data used in this study are from the field survey of 128 administrative villages in 13 cities of Jiangsu. 800 questionnaires were sent out and 726 were recovered. After eliminating the invalid information questionnaire, 671 valid questionnaires remained, with an effective rate of $83.9 \%$. According to the basic characteristics of the sample, 453 were women, accounting for $68 \%$; population under 35 years old accounted for $72 \%$; family members with the highest degree of university or above accounted for $35 \%$; nearly half of the annual family income is 50,000-100,000 CNY. The household waste disposal behavior of sample farmers is shown in Fig. 1. Generally speaking, majority of rural households can properly dispose of household waste.

\section{Research method}

\section{Logit model}

There are two ways for household garbage disposal: random and proper, which belong to the typical binary variables. Therefore, Logit Model should be adopted. The derivation of the model is as follows. The actual reaction variable is $y_{k}$, with a value of 0 and 1. Explanatory variables are represented by $x_{k}$, and error is represented by $\varepsilon_{k}$. Assuming that there is a linear relationship between $y_{k}{ }^{*}$ and $x_{k}$, namely $(E q .1)$

$$
y_{k}^{*}=\alpha+\beta x_{k}+\varepsilon_{k}
$$

There is a critical point $c$, when $y_{k}{ }^{*}>c$, then $y_{k}=1$, when $y_{k}{ }^{*} \leq c$, then $y_{k}=0$. Assuming that the critical point $c=0$, the error term $\varepsilon_{k}$ obeys Logistic distribution and its cumulative distribution function is $F($.$) , and p_{k}$ is the probability of occurrence of case $k$, there is (Eq. 2):

$$
\begin{aligned}
p_{k}=P\left(y_{k}\right. & \left.\left.=1 \mid x_{k}\right)=P\left[\left(\alpha+\beta x_{k}+\varepsilon_{k}\right)\right\rangle O\right] \\
& =P\left(\varepsilon_{k}\left\langle\alpha+\beta x_{k}\right)\right. \\
& =F\left(\alpha+\beta x_{k}\right) \\
& =\frac{\exp \left(\alpha+\beta x_{k}\right)}{1+\exp \left(\alpha+\beta x_{k}\right)}
\end{aligned}
$$

After logarithmic transformation, the above formula can be transformed into Eq. 3:

$$
\ln \left(\frac{p_{k}}{1-p_{k}}\right)=\alpha+\beta x_{k}
$$

Among them, $p_{k}$ is the probability of occurrence of case $k$. It is a non-linear function consisting of the explanatory variable $x_{k}$. When there are $\mathrm{N}$ independent variables, the binary regression model and its logarithmic transformation are shown in Eq. 4 and Eq. 5, respectively. 


$$
\begin{aligned}
& p_{k}=P\left(y_{k}=1 \mid x_{1 k}, x_{2 k}, \ldots, x_{n k}\right)=\frac{\exp \left(\alpha+\sum_{n=1}^{N} \beta_{n} x_{n k}\right)}{1+\exp \left(\alpha+\sum_{n=1}^{N} \beta_{n} x_{n k}\right)} \\
& \ln \left(\frac{p_{k}}{1-p_{k}}\right)=\alpha+\sum_{n=1}^{N} \beta_{n} x_{n k}(k=1,2 \ldots K, n=1,2 \ldots N)
\end{aligned}
$$

For this study, $p$ is the probability of household waste disposal properly, 1- $p$ is the probability of household waste disposal randomly; $\alpha$ is the constant of regression equation of various factors; $\beta_{i}$ is the coefficient of regression equation of various factors; $x_{i}$ is a variety of influencing factors; $n$ is the number of influencing factors. Maximum likelihood (ML) is generally used to estimate the parameters. For case $i$, there is a distribution function $(E q .6)$ :

$$
p\left(Y_{i}\right)=p_{i}^{Y_{i}}\left(1-p_{i}\right)^{1-Y_{i}}
$$

Then the logarithmic likelihood function is (Eq. 7):

$$
\begin{gathered}
l(\beta)=\sum_{i=1}^{n}\left(Y_{i} \ln p_{i}+\left(1-Y_{i}\right) \ln \left(1-p_{i}\right)\right) \\
=\sum_{i=1}^{n}\left(Y_{i} \ln \frac{p_{i}}{1-p_{i}}+\ln \left(1-p_{i}\right)\right) \\
=\sum_{i=1}^{n}\left(Y_{i}\left(X_{i} \beta\right)-\ln \left(1+\exp \left(X_{i} \beta\right)\right)\right)
\end{gathered}
$$

In order to estimate the value of $\beta$, we can derive the partial derivative of $l(\beta)$ over $\beta$ and make it equal to $0(E q .8)$ :

$$
\begin{gathered}
\frac{\partial l(\beta)}{\partial \beta_{1}}=\sum_{i=l}^{n}\left(Y_{i}-\frac{X_{i} \beta}{1+\exp \left(X_{i} \beta\right)}\right)=0 \\
\frac{\partial l(\beta)}{\partial \beta_{j}}=\sum_{i=l}^{n}\left(Y_{i}-\frac{X_{i} \beta}{1+\exp \left(X_{i} \beta\right)}\right) X_{j i}=0, j=2, \ldots, k
\end{gathered}
$$

\section{ISM method}

ISM method can transform vague ideas into well-structured models by using people's knowledge as well as the help of computer (Warfield, 1974). The main steps of ISM method are as follows. Step 1: Drawing the corresponding digraph according to Boolean operation. Then, constructing adjacent matrix A. Where $a$ satisfies Eq. 9. Step 2: Establishing the reachable matrix M. Operations are defined as Eq. 10. Step 3: Obtaining reduced matrix of reachable matrix. Step 4: The reduced matrix is processed hierarchically, and the interpretative structure model is obtained. 


$$
\begin{aligned}
& a_{i j}=\left(\begin{array}{l}
1, S_{i} R S_{j}, R \text { says } S_{i} \text { has a relationship with } S_{j} \\
0, S_{i} \bar{R} S_{j}, \bar{R} \text { says } S_{i} \text { has no relationship with } S_{j}
\end{array}\right. \\
& \text { if }(A+I)^{r}=(A+I)^{r+1} \neq(A+I)^{r-1}, M=(A+I)^{r}
\end{aligned}
$$

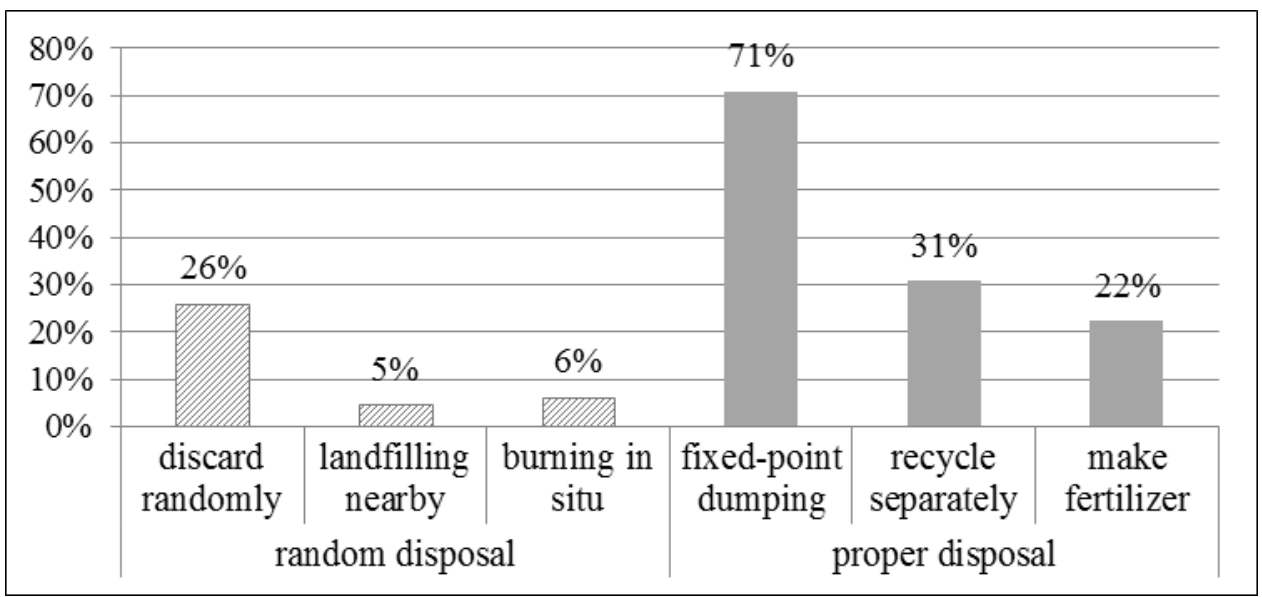

Figure 1. Household waste disposal behavior of sample farmers

\section{Results and discussions}

\section{Logit model regression results}

Firstly, we consider the relationship between all independent variables and dependent variables separately, screen out some variables that may not be meaningful, and then conduct multivariate analysis. Results shown in Model 1 in Table 2 indicate that variables that may have statistical significance include: X1, X4, X6, X7, X8, X12, X13, X14, X15, X16, X17, X18, X19, X20, X21, X22, X23, and X24. Secondly, after eliminating the insignificant variables, the variables other than X21 and X22 are put into the Logit model according to Forward: LR rules. As shown in Model 2 in Table 2, six variables have passed the significance test (Eq. 11).

$$
\begin{array}{r}
y=\ln \left(\frac{p}{1-p}\right)=0.602-0.368 \times \mathrm{X} 8+0.462 \times \mathrm{X} 12+0.623 \times \mathrm{X} 13 \\
-0.311 \times \mathrm{X} 17-0.735 \times \mathrm{X} 20+1.516 \times \mathrm{X} 23
\end{array}
$$

The regression results show that: The stronger the identifying capacity for pollutants, the better the household waste can be properly disposed of. Farmers who choose traditional fuels are more likely to dispose waste randomly. Farmers with wages as the main source of livelihood are more inclined to properly dispose of household waste. The village has a fixed-point waste disposal policy and the implementation effect is good, farmers are more likely to show standard waste disposal behavior, and vice versa. Whether there is a centralized waste disposal facility is closely related to the farmers' household waste disposal behavior. If neighbors can take appropriate disposal ways, farmers themselves tend to adopt the similar ways. 
Table 2. Logit model regression results

\begin{tabular}{|c|c|c|c|c|c|c|}
\hline Factor & Model1 & & Model2 & & Model3 & \\
\hline & B & Sig. & B & Sig. & B & Sig. \\
\hline $\mathrm{X} 1$ & $0.508 * * *$ & 0.006 & & 0.111 & & \\
\hline $\mathrm{X} 2$ & -0.021 & 0.874 & - & - & & \\
\hline $\mathrm{X} 3$ & 0.001 & 0.996 & - & - & & \\
\hline $\mathrm{X} 4$ & $0.162 * *$ & 0.015 & & 0.446 & & \\
\hline X5 & -0.094 & 0.103 & - & - & & \\
\hline X6 & $-0.287 * * *$ & 0.001 & & 0.716 & & \\
\hline X7 & $-0.337 * * *$ & 0.005 & & 0.338 & & \\
\hline $\mathrm{X} 8$ & $-0.347 * * *$ & 0.008 & $-0.368 * *$ & 0.015 & -0.500 & 0.006 \\
\hline $\mathrm{X} 9$ & -0.175 & 0.118 & - & - & & \\
\hline X10 & -0.067 & 0.435 & - & - & & \\
\hline X11 & 0.143 & 0.180 & - & - & & \\
\hline X12 & $0.957 * * *$ & 0.000 & $0.462 * *$ & 0.048 & 0.562 & 0.046 \\
\hline $\mathrm{X} 13$ & $1.254 * * *$ & 0.000 & $0.623 * * *$ & 0.007 & 0.825 & 0.002 \\
\hline $\mathrm{X} 14$ & $-0.564 * * *$ & 0.000 & & 0.433 & & \\
\hline X15 & $-0.644 * * *$ & 0.000 & & 0.087 & & \\
\hline X16 & $-0.585 * * *$ & 0.000 & & 0.183 & & \\
\hline X17 & $-0.587 * * *$ & 0.000 & $-0.311 * * *$ & 0.001 & -0.171 & 0.170 \\
\hline X18 & $-0.603 * * *$ & 0.000 & & 0.346 & & \\
\hline X19 & $0.843 * * *$ & 0.000 & & 0.797 & & \\
\hline $\mathrm{X} 20$ & $-1.880 * * *$ & 0.000 & $-0.735 * * *$ & 0.005 & & \\
\hline $\mathrm{X} 21$ & $-0.694 * * *$ & 0.003 & & & & 0.231 \\
\hline $\mathrm{X} 22$ & $0.805 * * *$ & 0.000 & & & $0.508 * * *$ & 0.003 \\
\hline $\mathrm{X} 23$ & $1.987 * * *$ & 0.000 & $1.516 * * *$ & 0.000 & 1.341 & 0.000 \\
\hline $\mathrm{X} 24$ & $-0.573 * * *$ & 0.000 & & 0.085 & & \\
\hline
\end{tabular}

In the above analysis, X20 has passed the significant test, so it is necessary to further test the significance of Distance to centralized waste disposal facilities (X21) and Clearance of centralized waste dump site (X22). Firstly, 546 data are obtained by eliminating the NONE data selected under the variable X20. Then the other five variables selected by multivariate Logit analysis are used as control variables, and X21 and X22 are used as independent variables. As shown in Model 3 in Table 2, X22 passed the significant test. The more timely the disposal of waste centralized dump site is, the more appropriate waste disposal behavior can be promoted. X21 had no significant impact on Y. In conclusion, seven variables, X8, X12, X13, X17, X20, X22 and $\mathrm{X} 23$, have significant effects on household waste disposal behavior of farmers.

\section{ISM model analysis results}

In order to further determine the logical relationship and hierarchical structure among the seven factors identified above, this paper uses S1, S2, S3, S4, S5, S6 and S7 to represent those seven significant factors, namely Identifying capacity for pollutants (S1), Major domestic fuel (S2), Major economic source (S3), Fixed-point waste disposal policy and its implementation effect (S4), Availability of centralized waste disposal facility (S5), Clearance of centralized waste dump site (S6) and Neighbor's way of disposing household waste (S7). Combining the experience knowledge of experts, the logical relationship among the factors is determined (Fig. 2a). V denotes that row elements influence column elements; A indicates that column elements affect row elements; $\mathrm{O}$ indicates that there is no relationship between rows and columns. Then, the reachable matrix is obtained (Fig. 2b). Seven factors can be divided into three layers. 


\begin{tabular}{|c|c|c|c|c|c|}
\hline V & $\mathrm{O}$ & $\mathrm{O}$ & A & $\mathrm{O}$ & V \\
\hline $\mathrm{O}$ & $\mathrm{O}$ & $\mathrm{O}$ & $\mathrm{O}$ & A & S2 \\
\hline $\mathrm{O}$ & $\mathrm{O}$ & $\mathrm{O}$ & $\mathrm{O}$ & S3 & \\
\hline $\mathrm{O}$ & V & V & S4 & & \\
\hline V & $\mathrm{O}$ & S5 & & & \\
\hline $\mathrm{O}$ & S6 & & & & \\
\hline
\end{tabular}

S7

\begin{tabular}{l|c|c|c|c|c|c|c|} 
& \multicolumn{3}{c}{ S2 } & \multicolumn{1}{c}{ S6 } & \multicolumn{1}{c}{ S7 } & \multicolumn{1}{c}{ S1 } & \multicolumn{2}{c}{ S3 } & \multicolumn{2}{c}{ S5 } & \multicolumn{1}{c}{ S4 } \\
\cline { 2 - 8 } S & 1 & 0 & 0 & 0 & 0 & 0 & 0 \\
\cline { 2 - 8 } S6 & 0 & 1 & 0 & 0 & 0 & 0 & 0 \\
S7 & 0 & 0 & 1 & 0 & 0 & 0 & 0 \\
\cline { 2 - 8 } S1 & 1 & 0 & 0 & 1 & 0 & 0 & 0 \\
\cline { 2 - 8 } S3 & 1 & 0 & 0 & 0 & 1 & 0 & 0 \\
\cline { 2 - 8 } S5 & 0 & 0 & 1 & 0 & 0 & 1 & 0 \\
\cline { 2 - 8 } S4 & 1 & 1 & 1 & 0 & 1 & 1 & 1 \\
\cline { 2 - 8 } & & & & & &
\end{tabular}

a.

b.

Figure 2. Logical relationship among the factors and sorted reachability matrix

As can be seen from Fig. 3, variables at different levels have different effects on Y. Specifically: At the bottom is S4, which runs through almost all the important parts of the model and becomes the deep-seated root cause of affecting household waste disposal behavior of farmers. S1, S3 and S5 are located in the middle layer, which are important factors affecting Y. Moreover, the influence mode of S3 has certain independence. At the first level are S2, S6, and S7, which have direct impact on farmers' household waste disposal behavior. Meanwhile, S2 is affected by both S1 and $\mathrm{S} 3$ from the middle layer, and S7 is affected by S5.

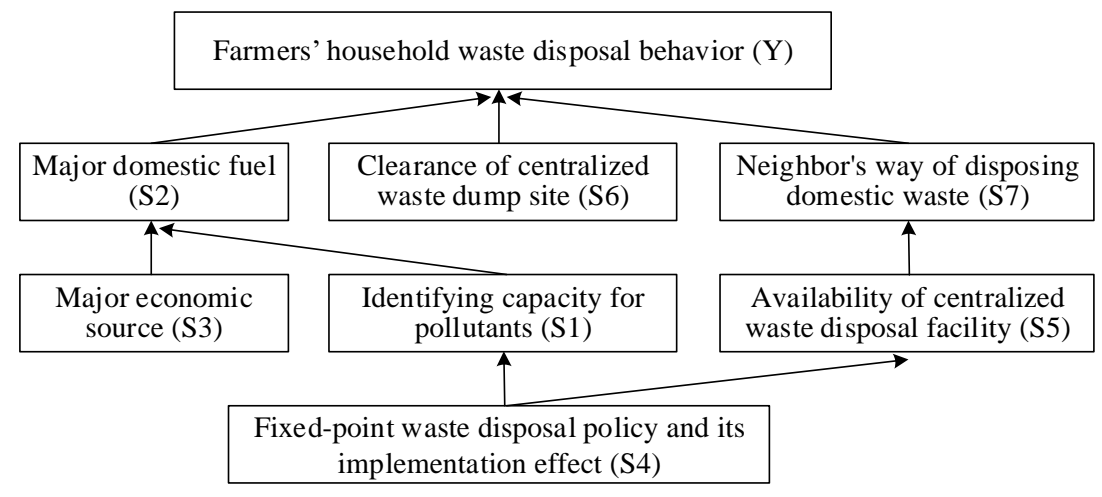

Figure 3. Interpretative structure model of influencing factors

\section{Result discussion}

As far as the physiological characteristics of farmers are concerned, Age (X2) and Cadre status (X3) have not passed the significant test, which is inconsistent with the research results of Yang et al. (2017). The reason may be that the development of the Internet has reduced the space-time distance, enabling everyone to receive information conveniently and timely, thus reducing the influence of individual differences. In univariate analysis, although Gender (X1) has a certain impact on the dependent variable, the impact of gender is weaker than other factors.

From the regression results of the psychological characteristics of farmers, only Identifying capacity for pollutants (X8) passed the significance test. On the one hand, 
Jiangsu paid more attention to the problem of rural household waste disposal. It began to publicize the consequences of waste discarding at will earlier, giving farmers a certain understanding of fixed-point waste disposal. Therefore, the samples have a small difference in the recognition of the relevant factors. On the other hand, the impact of other variables representing farmers' psychological characteristics on Y may have been included in the impact caused by $\mathrm{X} 8$, so they failed to pass the significance test. In addition, farmers may have certain psychological pressure when filling in the questionnaires face-to-face. They fail to give an objective assessment of the environment, resulting in the insignificant of X6.

For the family environment, Family educational level (X9) failed to pass the significant test. The reason may be the education situation of rural students in China. In China, schools above junior high school are generally distributed in cities and towns with more developed economy. Rural students need to leave home for a long time, causing them to lack enough opportunities to influence others. Because of the petty farmer idea has not been completely eliminated in China, the improvement of economic conditions will not significantly promote farmers to adopt appropriate waste disposal behavior, resulting in the insignificant of X10. The reason why Number of migrant workers (X11) is not significant is that most families have less migrant workers, and the level of work is not very high.

In terms of social environment, the reason why X19, X14 and X15 are not significant is also because of Jiangsu has attached great importance to rural waste management, narrowing the gap between villages in terms of these factors. Meanwhile, propaganda, education and behavioral management measures can be regarded as part of the policy system. The impact of X14, X15 and X16 on dependent variable may have been included in the impact caused by Fixed-point waste disposal policy and its implementation effect (X17), so these variables have not passed the significance test, which is another possible reason why X19 is not significant.

The reason why Distance to the city center (X24) has not passed the significance test lies in Jiangsu's dense population. On the whole, the geographical space separation between rural and urban areas is not very large, thus the results of questionnaire show little difference in this factor, affecting the result of the significance test.

The intrinsic reasons for the influence of Major domestic fuel (X12) on Y are Major economic source (X13) and Identifying capacity for pollutants (X8). Families whose economic sources are mainly wages are relatively affected by the living habits of urban residents, and more likely to use modern living fuels. Moreover, farmers with wages as their main source of economy are more able to afford modern energy. Besides, the more familiar farmers are with environmental protection knowledge, the more willing they are to adopt pro-environmental behavior (Estrada et al., 2017), and more willing to use less polluted domestic fuels.

The impact of Fixed-point waste disposal policy and its implementation effect (X17) runs through the whole process. If the relevant policies can be promulgated and implemented, it can directly increase investment in waste centralized treatment facilities, increase the frequency of waste pool cleaning, and then promote farmers to adopt appropriate ways of household waste treatment. Meanwhile, X17 can promote the popularization of environmental protection knowledge in a wider range, so that more farmers are aware of the hazards of random disposal of household waste, and have the ability to identify pollutants. Therefore, they are more willing to make environmentally friendly behavior, such as using clean fuels. 


\section{Conclusions}

Based on Lewin's behavior model and the data of 671 households in Jiangsu, this paper used Logit-ISM model to analyze farmers' household waste disposal behavior and its influencing factors. The results show that seven factors have significant effects on household waste disposal behavior, namely Identifying capacity for pollutants (X8), Major domestic fuel (X12), Major economic source (X13), Fixed-point waste disposal policy and its implementation effect (X17), Availability of centralized waste disposal facility (X20), Clearance of centralized waste dump site (X22) and Neighbour's way of disposing household waste (X23).

The stronger the ability of farmers to discriminate pollutants, the more willing they are to dispose of waste properly. Compared with the areas without fixed-point disposal policy of household waste, those have ones tend to show standardized disposal behaviour of household waste. In areas where centralized waste disposal facilities are available and can be cleaned in time, farmers tend to dispose of household waste properly. Using coal, wood and other traditional energy as main fuel and taking farming as the main source of livelihood have a certain negative impact on farmers' proper waste disposal behavior. Neighbors' disposal of household waste will have a strong assimilation effect on individual's behavior of household waste disposal.

At the same time, there are mutual influences among these seven significant factors. $\mathrm{X} 17$ is a deep-seated influencing factor, which has a root effect on farmers' household waste disposal behavior. X8, X13 and X20 are the middle factors. X13 has certain independent impact. X8 and X20 are the nodes that connect the deep factors with surface factors, and play a key intermediary role. X12, X22 and X23 have direct impact, belonging to surface factors.

Based on above conclusions, we put forward the following suggestions: First, establish a long-term mechanism of fixed-point treatment of rural household waste, strengthen the effect of policy implementation. Second, strengthen the propaganda of environmental protection knowledge, especially focusing on the popularization among farmers, and encourage them to replace traditional fuels with clean energy. Third, add waste collection and treatment facilities such as garbage cans, garbage tanks and garbage collection trucks, and clean up these facilities in time. Fourth, set up models, commend and reward villages achieving remarkable results in the treatment of household waste, giving full play to the exemplary driving effect.

Although this paper explored the influencing factors of farmers' household waste disposal behavior in Jiangsu Province and put forward the corresponding countermeasure proposals through qualitative and empirical research, due to time constraints and data acquisition constraints, the research still need to be further investigated. On the one hand, through the case study of typical villages, the impact degree of each influencing factor can be refined with the help of structural equation model, so as to further improve the effectiveness of the policy. On the other hand, future research can be done based on the theory of planned behavior (TPB) in social psychology, or from the perspective of A-B-C theory.

Acknowledgements. This work was supported by the Project funded by China Postdoctoral Science (2019M650456), by the Fundamental Research Funds for the Central Universities (ZY1915, buctrc201804), and by the National Natural Science Foundation of China (71532003). 


\section{REFERENCES}

[1] Abbott, A., Nandeibam, S., O'Shea, L. (2013): Recycling: Social norms and warm-glow revisited. - Ecological Economics 90: 10-18.

[2] Arcury, T. A. (1990): Environmental attitude and environmental knowledge. - Human organization 49: 300-304.

[3] Bamberg, S. (2003): How does environmental concern influence specific environmentally related behaviors? A new answer to an old question. - Journal of Environmental Psychology 23: 21-32.

[4] Catton, W. R., Dunlap, R. E. (1978): Environmental sociology: A new paradigm. American Sociologist 13: 41-49.

[5] Czajkowski, M., Hanley, N., Nyborg, K. (2017): Social norms, morals and self-interest as determinants of pro-environment behaviours: The case of household recycling. Environmental and Resource Economics 66: 647-670.

[6] D'Amato, A., Mancinelli, S., Zoli, M. (2016): Complementarity vs substitutability in waste management behaviors. - Ecological Economics 123: 84-94.

[7] Dorina, G. (2016): Assessing the variables affecting on the rate of solid waste generation and recycling: An empirical analysis in Prespa Park. - Waste Management 48: 3-13.

[8] Du, J., Li, Q., Qiao, F., Yu, L. (2018): Estimation of vehicle emission on mainline freeway under isolated and integrated ramp metering strategies. - Environmental Engineering and Management Journal 17(5): 1237-1248.

[9] Estrada, M., Schultz, P. W., Silva-Send, N., Boudrias, M. A. (2017): The role of social influences on pro-environment behaviors in the San Diego Region. - Journal of Urban Health 94: 170-179.

[10] Gong, D., Tang, M., Liu, S., Xue, G., Wang, L. (2019): Achieving sustainable transport through resource scheduling: A case study for electric vehicle charging stations. Advances in Production Engineering \& Management 14(1): 65-79.

[11] Guagnano, G. A., Stern, P. C., Dietz, T. (1995): Influences on attitude-behavior relationships: A natural experiment with curbside recycling. - Environment and Behavior 27: 699-718.

[12] Hage, O., Sandberg, K., Söderholm, P., Berglund, C. (2018): The regional heterogeneity of household recycling: a spatial-econometric analysis of Swedish plastic packing waste. Letters in Spatial and Resource Sciences 11: 245-267.

[13] Hakami, B. A., Seif, E. S. S. A. (2015): Household solid waste composition and management in Jeddah City, Saudi Arabia: a planning model. - International Research Journal of Environment Sciences 4: 1-10.

[14] Han, Z., Liu, Y., Zhong, M., Shi, G., Li, Q., Zeng, D., Zhang, Y., Fei, Y., Xie, Y. (2018): Influencing factors of domestic waste characteristics in rural areas of developing countries. - Waste Management 72: 45-54.

[15] Huang, K. X., Wang, J. X., Bai, J. F., Qiu, H. G. (2012): Production of rural domestic solid waste and policy countermeasures. - China Soft Science 9: 72-79.

[16] Jenkins, R. R., Martinez, S. A., Palmer, K., Podolsky, M. J. (2003): The determinants of household recycling: a material-specific analysis of recycling program features and unit pricing. - Journal of Environmental Economics and Management 45: 294-318.

[17] Jiang, T. B., Yuan, J. Z. (2013): The analysis of factors affecting farmers' life trash disposal behavior in the urban and rural balancing development. - Ecological Economy 2013: 161164.

[18] Jin, Y., Ma, X., Chen, X., Cheng, Y., Baris, E., Ezzati, M. (2006): Exposure to indoor air pollution from household energy use in rural China: the interactions of technology, behavior, and knowledge in health risk management. - Social Science \& Medicine 62: 3161-3176.

[19] Kuo, Y. L., Perrings, C. (2010): Wasting Time? Recycling incentives in urban Taiwan and Japan. - Environmental and Resource Economics 47: 423-437. 
[20] Lee, M., Choi, H., Koo, Y. (2017): Inconvenience cost of waste disposal behavior in South Korea. - Ecological Economics 140: 58-65.

[21] Li, T., Espínola-Arredondo, A., McCluskey, J. J. (2016): Promoting residential recycling: An alternative policy based on a recycling reward system. - Games 7: 1-18.

[22] Ma, Y., Chen, L., Zhao, X., Zheng, H., Lü, Y. (2009): What motivates farmers to participate in sustainable agriculture? Evidence and policy implications. - International Journal of Sustainable Development \& World Ecology 16: 374-380.

[23] Milfont, T. L. (2012): The interplay between knowledge, perceived efficacy, and concern about global warming and climate change: A one-year longitudinal study. - Risk Analysis 32: 1003-1020.

[24] Miliute-Plepiene, J., Hage, O., Plepys, A., Reipas, A. (2016): What motivates households recycling behaviour in recycling schemes of different maturity? Lessons from Lithuania and Sweden. - Resources, Conservation and Recycling 113: 40-52.

[25] Oyekale, A. S. (2018): Determinants of households' involvement in waste separation and collection for recycling in South Africa. - Environment, Development and Sustainability 20: 2343-2371.

[26] Petraru, M., Gavrilescu, M. (2010): Pollution prevention, a key to economic and environmental sustainability. - Environmental Engineering \& Management Journal 9: 597614.

[27] Poortinga, W., Steg, L., Vlek, C., Wiersma, G. (2003): Household preferences for energysaving measures: A conjoint analysis. - Journal of Economic Psychology 24: 49-64.

[28] Refsgaard, K., Magnussen, K. (2009): Household behaviour and attitudes with respect to recycling food waste-experiences from focus groups. - Journal of Environmental Management 90: 760-771.

[29] Schahn, J., Holzer, E. (1990): Studies of individual environmental concern: The role of knowledge, gender, and background variables. - Environment and Behavior 22: 767-786.

[30] Seacat, J. D., Boileau, N. (2018): Demographic and community-level predictors of recycling behavior: A statewide, assessment. - Journal of Environmental Psychology 56: 12-19.

[31] Steg, L. (2008): Promoting household energy conservation. - Energy Policy 36: 4449-4453.

[32] Struk, M. (2017): Distance and incentives matter: The separation of recyclable municipal waste. - Resources, Conservation and Recycling 122: 155-162.

[33] Videras, J., Owen, A. L., Conover, E., Wu, S. (2012): The influence of social relationships on pro-environment behaviors. - Journal of Environmental Economics and Management 63: $35-50$.

[34] Wang, E., Kang, N. (2019): Does life satisfaction matter for pro-environmental behavior? empirical evidence from China general social survey. - Quality \& Quantity 53: 449-469.

[35] Warfield, J. N. (1974): Toward interpretation of complex structural models. - IEEE Transactions on Systems, Man, and Cybernetics 4: 405-417.

[36] Yang, R., Long, R., Bai, Y., Li, L. (2017): The influence of household heterogeneity factors on the green travel behavior of urban residents in the East China region. - Sustainability 9: $1-17$.

[37] Yokoo, H. F., Kawai, K., Higuchi, Y. (2018): Informal recycling and social preferences: Evidence from household survey data in Vietnam. - Resource and Energy Economics 54: 109-124.

[38] Young, R. D. (1990): Recycling as appropriate behavior: a review of survey data from selected recycling education programs in Michigan. - Resources Conservation \& Recycling 3: 253-266.

[39] Zeng, J., Zhou, S., Lv, L., Su, Q., Wang, J. (2018): Soil heavy metal contamination in rural land consolidation areas in the Yangtze River Delta, China. - Journal of Environmental Engineering and Landscape Management 26: 28-37.

[40] Zhang, Y., Gao, Y., Duan, J. (2013): Control mode of rural nonpoint source pollution in Tai Lake Basin, China. - Environmental Engineering \& Management Journal 12: 1359-1365. 